\title{
The Implementation of Ground Response Analysis to Quantify Liquefaction Potential Index (LPI) in Bengkulu City, Indonesia
}

\author{
Lindung Zalbuin Mase ${ }^{1^{\star}}$, Muhammad Farid ${ }^{2}$, Nanang Sugianto ${ }^{2}$, Sintia Agustina ${ }^{1}$ \\ Department of Civil Engineering, Faculty of Engineering, University of Bengkulu, INDONESIA \\ JI WR. Supratman Kandang Limun, Muara Bangkahulu, Bengkulu, 38371 A, \\ ${ }^{2}$ Department of Geophysics, Faculty of Math and Natural Sciences, University of Bengkulu, INDONESIA \\ JI WR. Supratman Kandang Limun, Muara Bangkahulu, Bengkulu, 38371A \\ "Corresponding authors: Imase@unib.ac.id
}

SUBMITTED 1 July 2020 REVISED 30 July 2020 ACCEPTED 12 August 2020

\begin{abstract}
Bengkulu City is one of the areas vulnerable to earthquakes in Indonesia and several studies have shown the city experienced a unique phenomenon called liquefaction during the $M_{w} 8.6$ Bengkulu-Mentawai Earthquake. This event has initiated a step by step intensive study on earthquake in the area but previous studies are generally limited by the use of site investigation data to empirically analyse liquefaction potential and those that used advance method such as the seismic wave propagation model are rare. This means the level of liquefaction damage in the study area is not totally understood, therefore, this research focused on implementing the ground response analysis to quantify the Liquefaction Potential Index (LPI) using several areas in Bengkulu City in order to determine their vulnerability. The process involved the collection of several site investigation data including boring log and shear wave velocity profile as well as a desk study to determine the geological condition of the observed sites. Moreover, a non-linear seismic ground response analysis was conducted to obtain maximum ground surface acceleration ( $a_{\max }$ ) parameter which was further used to analyse the liquefaction potential in the study area. The results showed several sites have the potential to experience liquefaction during earthquakes. The method applied was considered successful and the results are expected to be implemented for city development. Furthermore, the framework is recommended for adoption in investigating the liquefaction in other areas.
\end{abstract}

KEYWORDS Ground Response; Liquefaction Potential; Bengkulu City; Peak Ground Acceleration; Earthquake.

( The Author(s) 2020. This article is distributed under a Creative Commons Attribution-ShareAlike 4.0 International license.

\section{INTRODUCTION}

Bengkulu City in Indonesia has been reported to be very vulnerable to earthquake and this associated with several tectonic sources such as Sumatra Subduction, Sumatra Fault, and Mentawai Fault surrounding the area (Mase, 2020a). Moreover, Mase (2017) reported that a major $\mathrm{M}_{\mathrm{w}}$ 8.6 Bengkulu-Mentawai Earthquake shown in Figure 1 triggered liquefaction in the city and this has led to several studies by some local researchers.

Misliniyati et al. (2014) studied the liquefaction potential based on probabilistic seismic hazard analysis in Lempuing Subdistrict and found the area to be very vulnerable due to the occurrence of earthquakes with magnitude more than $\mathrm{M}_{\mathrm{w}} 7$. Mase and Somantri (2016) also conducted a site investigation along the coastal area of Bengkulu City and concluded that sandy soil layers along the coastline are vulnerable to liquefaction. Moreover, Mase and Somantri (2016) also confirmed the experimental results presented by Mase (2015) showing the possible vulnerability of the grain size distribution of marine sands in the city's coastline. Mase (2018) examined the empirical method of liquefaction potential analysis conducted by Idriss and Boulanger (2006) and concluded that the method is important to the liquefaction preliminary analysis in Bengkulu City. Farid and Hadi (2018) conducted a microtremor measurement to obtain the geophysical characteristics of Bengkulu City and also showed the sediment materials, which are dominated by sandy soils, 


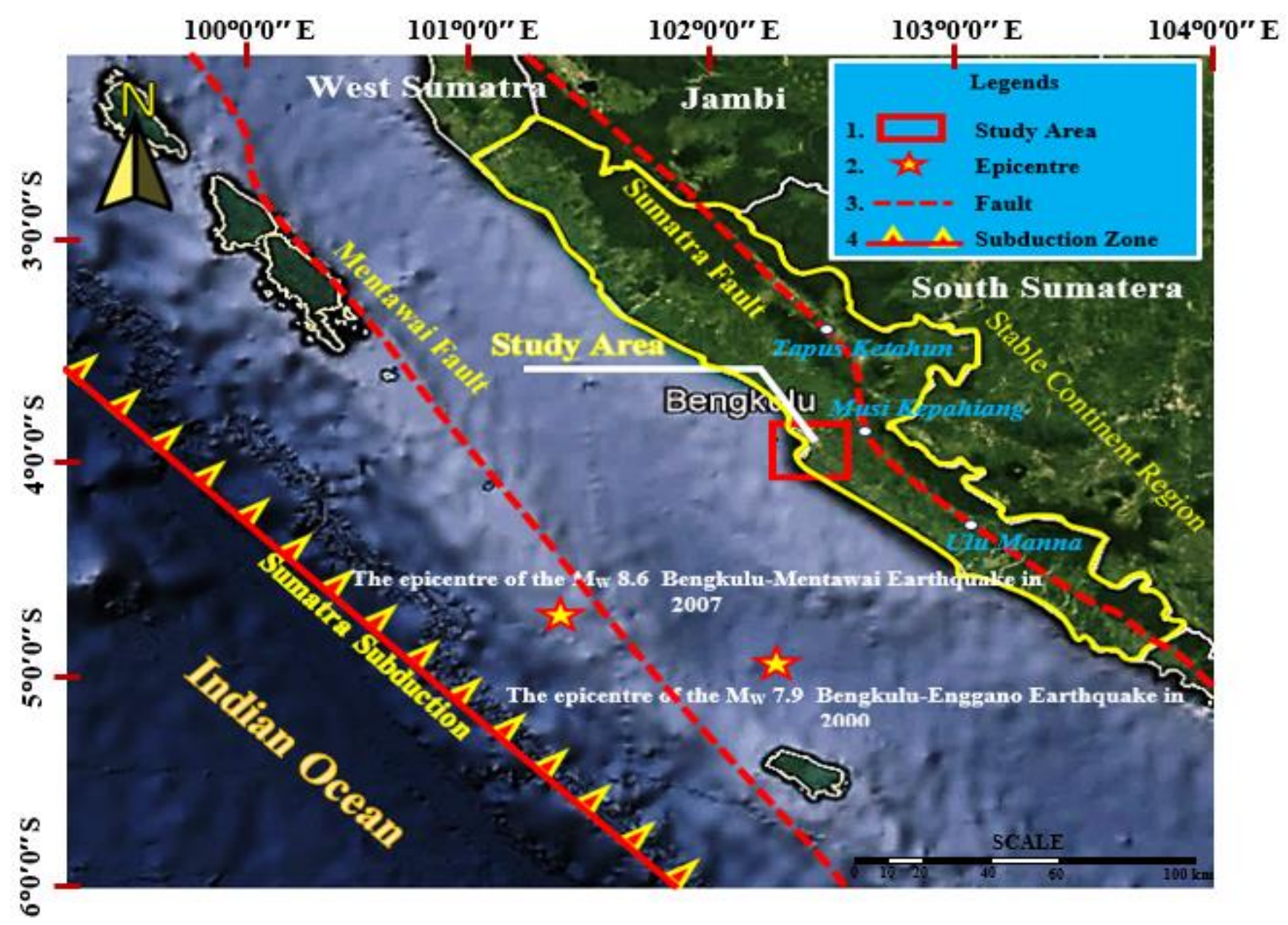

Figure 1. The seismotectonic setting of Bengkulu Province (modified Mase, 2020a)

were liquefied during the $\mathrm{M}_{\mathrm{w}} 7.9$ BengkuluEnggano Earthquake of 4 June 2000. Furthermore, Mase (2018 and 2020b) implemented a non-linear seismic ground response method to investigate soil behaviour along the coastal area of the city and the findings are generally consistent with previous studies which focused on liquefaction potential assessment based on site investigation data and ground response analysis. There is, however, rare application of non-linear ground response and empirical analyses combination to measure the liquefaction potential of the overall site.

This study implemented non-linear ground response analysis to quantify the liquefaction potential index (LPI) (Iwasaki, 1982) without concentrating only on the coastline areas but also several sites in Bengkulu City. The analysis was conducted to determine the peak ground acceleration parameter which is usually used as an input in the empirical analysis of liquefaction. Moreover, the LPI method was used to estimate the liquefaction vulnerability in the study area. This research, therefore, intends to promote the combination of two liquefaction analysis methods in engineering practice.

\section{METHODS}

\subsection{Study Area}

This study area includes 10 sites including SI-1 to SI-10 which were investigated as indicated in Figure 2. They were selected to represent the geological conditions and characteristics of different parts of Bengkulu City. This is important considering the six geological formations found in the city which are bintunan formation $(\mathrm{QTb})$, alluvium $(\mathrm{Qa})$, reef limestone (QI), swamp deposits (Qs), alluvium terraces (Qat), and andesite (Tpan) with the Qat generally 


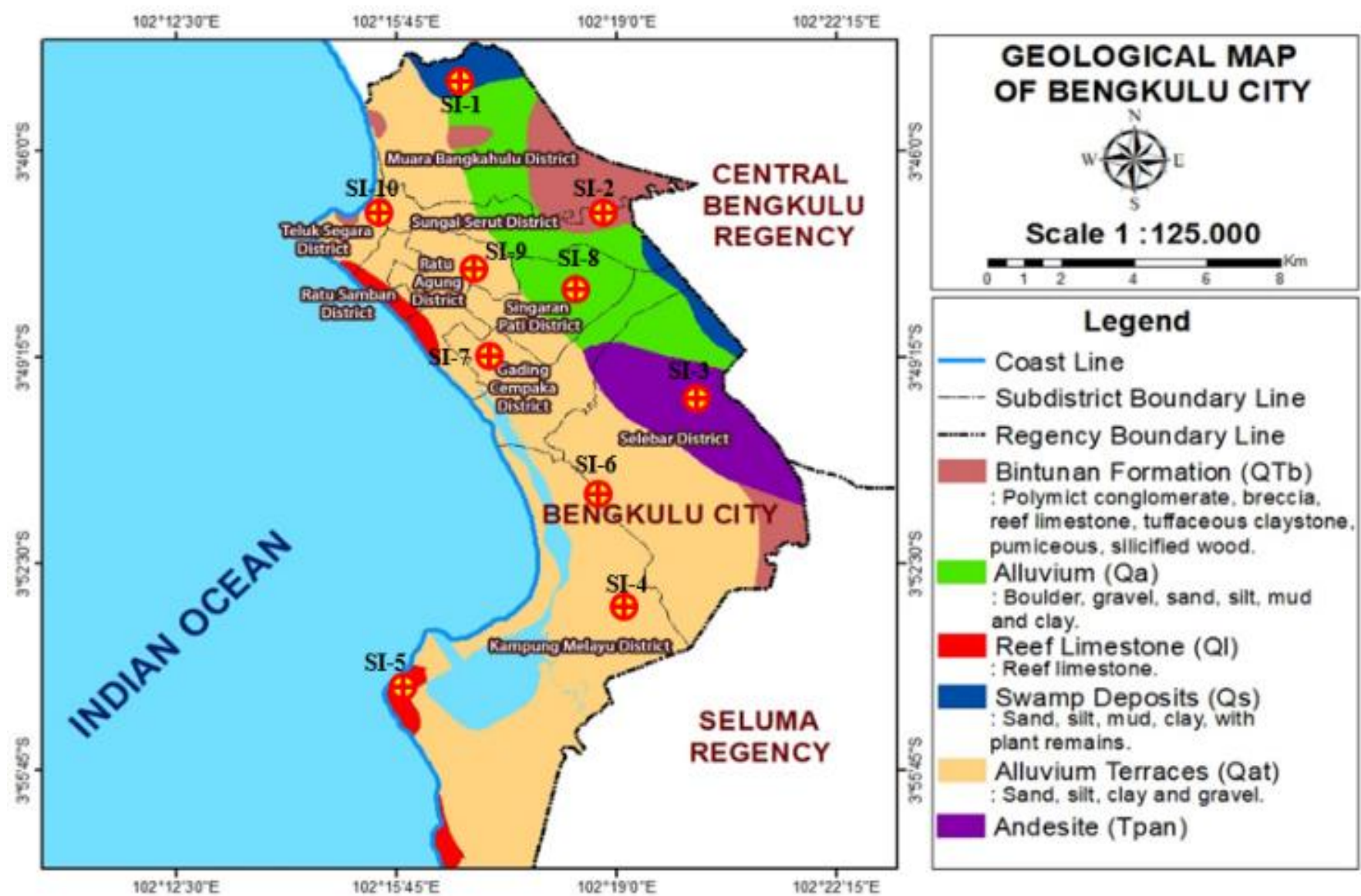

Figure 2. Geologic map of Bengkulu City and locations of investigated sites (modified from Mase, 2020a and BPBD, 2018)

found to be the dominant formation and it contains sand, silt, clay, and gravel (National Agency of Natural Hazard for Bengkulu City or BPBD, 2018). The information on the subsoils at the first $30 \mathrm{~m}$ depth was collected as shown in Figure 3 and found to be dominated by sandy layers. Several sites including SI-1, SI-4, SI-5, and SI-8 are totally dominated by sandy soils which are further classified as poor-graded sand (SP), silty sand (SM), clayey sand (SC), gravelly sand (SG), and well-graded sand (SW). Some thin clay layers were also observed on SI-2, SI-3, SI-6, SI-7, SI-9, and SI-10 and are also generally classified as high-plasticity clay $(\mathrm{CH})$, lowplasticity clay (CL), organic clay $(\mathrm{OH})$, and silty clay (CM). In terms of soil resistance, the shear wave velocity $\left(V_{s}\right)$ on each site was found to be increasing with dept and this means deeper soils have higher soil resistance. Moreover, the estimated time-averaged shear wave velocity for the first $30 \mathrm{~m}\left(V_{s 30}\right)$ depth was discovered to be generally between 280 to $480 \mathrm{~m} / \mathrm{s}$. The investigated sites were also classified based on
National Earthquake Hazard Reduction Program or NEHRP (1998) into Site Class C which indicates soft rock and Site Class D which means stiff soil.

\subsection{Research Framework}

The study started with the collection of site investigation data to determine several parameters such as physical and soil strength properties. Moreover, a non-linear seismic ground response framework proposed by Elgamal et al. (2006) was adopted for analysis while an effective stress model developed based on incremental plasticity was implemented to determine soil dynamic parameters (Elgamal et al. 2006). The incremental plasticity and stiffness change were considered during cyclic loading due to their significance in determining the permanent deformation and realistic hysteretic loop. Furthermore, a finite element method with coupled solid-fluid approach was used in calculating both dry and saturated strata in order to observe soil behaviour during earthquakes. A 

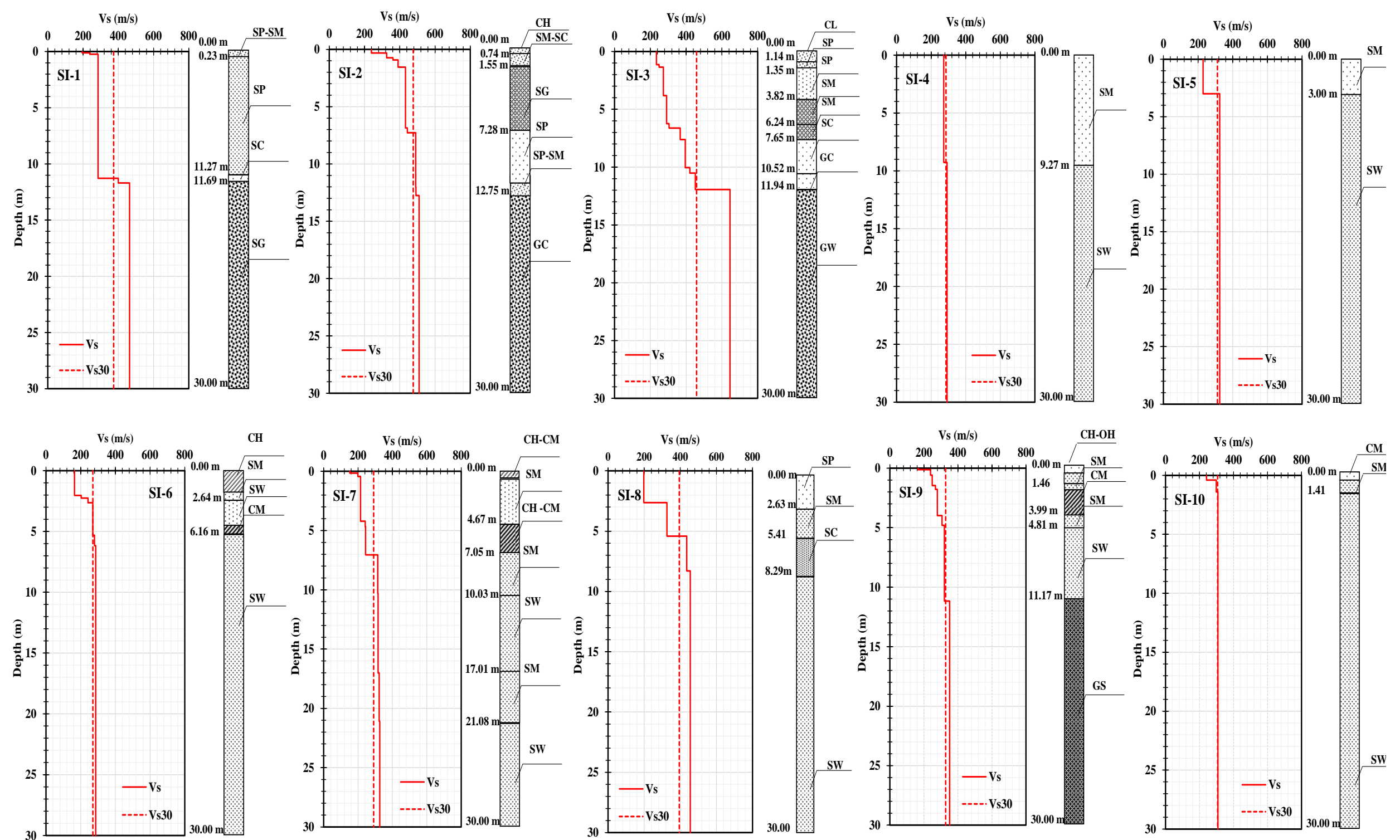

Figure 3 . The site investigated in this stud 
phase transformation was observed in the sandy soils during the dynamic loading and this is due to the cyclic mobility required by the soil to undergo dilation and extension. The complex phenomenon was handled with non-linear parameters such as peak shear strain (PSS), the number of yield surface (NYS), dilative parameters ( $\mathrm{d} 1$ and $\mathrm{d} 2$ ), contractive parameters (c1 and c2), and liquefaction parameter (Liq) which are generally obtained based on the recommendation from Elgamal et al. (2006) and introduced during the cyclic mobility. Meanwhile, one-dimensional non-linear ground response analysis has been presented by several researchers such as Pender et al. (2016) and Mase (2018) as shown in Figure 4 while the groundwater level was assumed to be on the surface to reflect the most critical condition (Kramer, 1996). In Figure 4, the soil profile is divided into elements computed based on wave propagation theory and the minimum size for each was reported by Pender et al. (2016) and Mase et al. (2017) to be $0.5 \mathrm{~m}$. The boundary conditions were limited on vertical direction of the soil column while there is no lateral direction at the bottom and this led to the adoption of elastic half-space assumption through the surface, $V_{s}$, of $760 \mathrm{~m} / \mathrm{s}$ which was assigned at the bottom of the soil column. This assumption has also been applied in several studies, such as Adampira et al. (2015) and Mase et al. (2018) to conduct seismic ground response analysis in Assaluyeh (Iran) and Chiang Rai (Thailand) respectively. Moreover, a ground motion generated based on earthquake characteristics proposed by Mase et al. (2019) was applied as the input motion as indicated in Figure 5. The ground motion of the $\mathrm{M}_{\mathrm{w}}$ 8.6 Bengkulu Mentawai Earthquake which has been noted as the most significant earthquake within the last 20 years was reflected (Mase, 2020a). The maximum ground surface acceleration $\left(a_{\max }\right)$ was also observed during the seismic wave propagation due to its ability to control the liquefaction potential and the estimation of its value was required by Mase (2019) to be accurate, especially for use in ground response analysis. It was later used to calculate the liquefaction potential of the study area and the groundwater level which was assumed at the ground surface was used to represent the conservative condition of the liquefaction (Kramer, 1996).

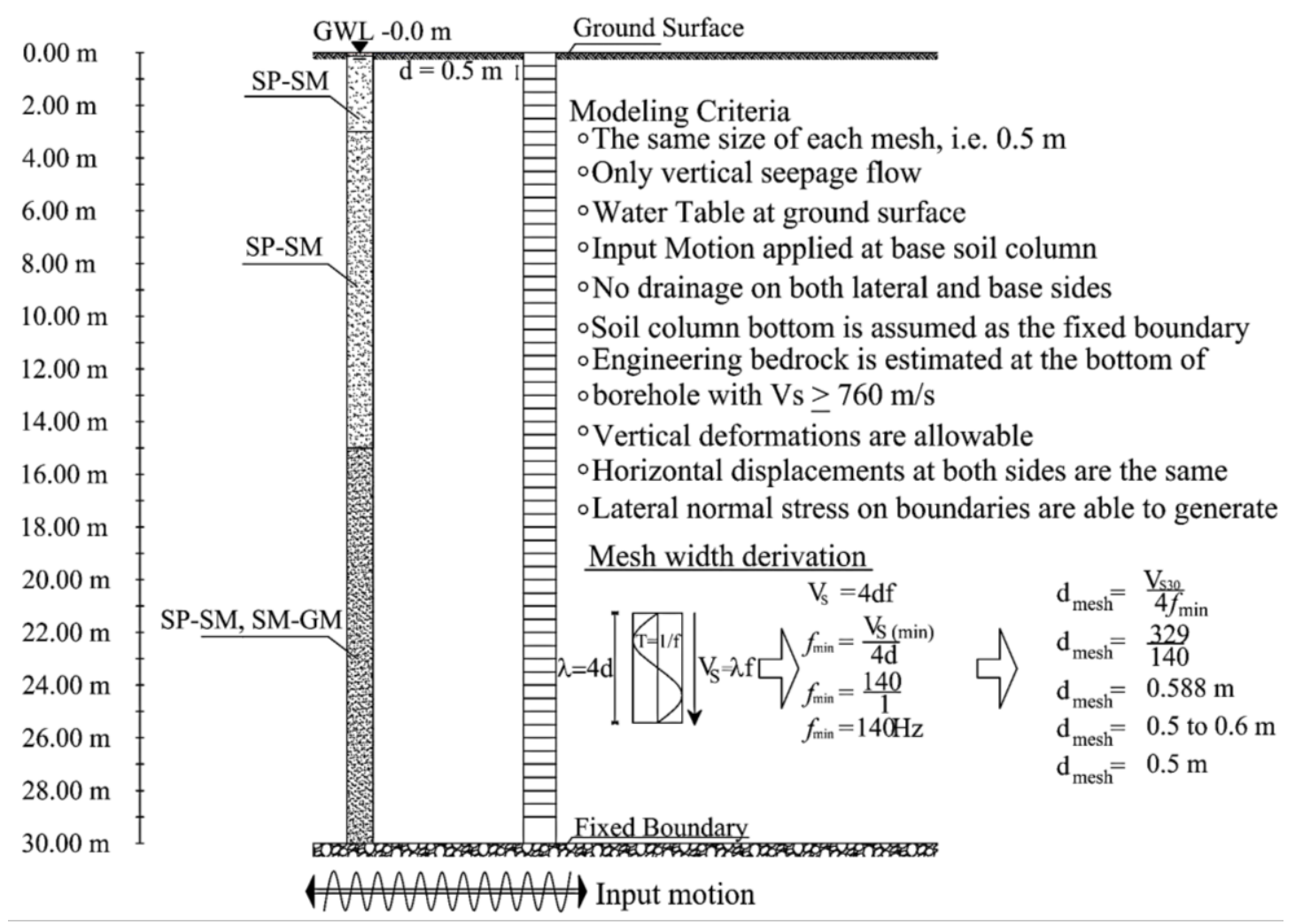

Figure 4. Schematic description of the one-dimensional seismic ground response framework (Mase, 2018) 


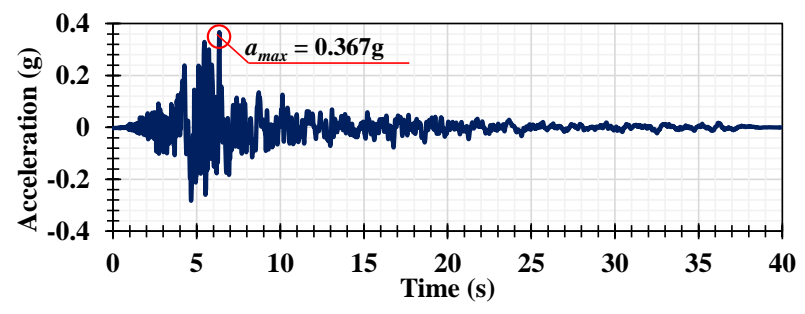

Figure 5. Input motion used in this study (Mase et al., 2019)

The empirical method of liquefaction potential analysis obtained based on $V_{s}$ data (Andrus et al., 2004) was used to determine the level of liquefaction vulnerability in the study area. First, the step was initiated by determining the cyclic stress ratio $(C S R)$, which is a parameter reflecting the stress ratio produced during the earthquake and expressed using the Equation (1a)-(1c).

$\operatorname{CSR}=0.65\left(\frac{a_{\max }}{g}()\left(\frac{\sigma_{v}}{\sigma_{v}^{\prime}}\right)_{d}\right)$

$r_{d}=1.0-0.00765 z$ for $z \leq 9.15 \mathrm{~m}$

$r_{d}=1.0-0.00765 z$ for $9.15 \mathrm{~m}<z \leq 23 \mathrm{~m}$

where, $a_{\max }$ is maximum ground surface acceleration, $g$ is gravity acceleration, $\sigma_{v}$ is the total stress of the depth analysed, $\sigma_{v}{ }^{\prime}$ is the initial effective stress of depth analysed, $r_{d}$ is stress reduction factor, and $z$ is the depth analysed.

The soil resistance against liquefaction is defined as the cyclic resistance ratio (CRR) and this is highly dependent on the soil strength properties. This means it is possible to simply predict the value based on the site investigation data. Moreover, $V_{s}$ was obtained from the geophysical survey and used as a parameter to determine $C R R$ as expressed in the Equation (2a) $-(2 f)$.

$$
\begin{aligned}
& C R R=\operatorname{MSF}\left\{0.022\left(K_{a 1} V_{s 1}\right)^{2}+2.8\left(\frac{1}{V_{S 1}^{*}-\left(K_{a 1} V_{S 1}\right)}-\right.\right. \\
& \left.\left.\quad \frac{1}{V_{S 1}^{*}}\right)\right\} K_{a 2} \\
& V_{S 1}=V_{S}\left(\frac{P_{a}}{\sigma_{v^{\prime}}}\right)^{0.25}\left(\frac{0.5}{K_{0}^{\prime}}\right)^{0.125} \\
& M S F=\left(\frac{M_{w}}{7.5}\right)^{-2.56} \\
& V_{S 1}^{*}=215 \mathrm{~m} / \mathrm{s} \quad \text { for } F C \leq 5 \%
\end{aligned}
$$

$V_{S 1}^{*}=215-0.5(F C-5) \quad$ for $5 \%<F C<35 \%$

$V_{s 1}^{*}=200 \mathrm{~m} / \mathrm{s}$ for $F C \geq 35 \%$

where, $M S F$ is the magnitude scaling factor, $V_{s 1}$ is a corrected $V_{s}, P_{a}$ is the atmospheric pressure, $K_{0}{ }^{\prime}$ is the effective lateral earth pressure at rest, $F C$ is fines content, $V_{s}^{*}$ is the referenced $V_{s}$ based on fine content while $K_{a 1}$ and $K_{a 2}$ are the age correction factor with the details presented in Andrus and Stokoe (2000) and Andrus et al. (2004).

The factor of safety against liquefaction $(F S)$ was generated after the two controlling factors of liquefaction which are $C S R$ and $C R R$ have been obtained. The FS reflects the stability of the soil under dynamic force generated by earthquake such that FS $<1$ means the possibility of liquefaction while $F S \geq 1$ means it is unlikely to happen based on the Equation (3).

$F S=\frac{C R R}{C S R}$

Iwasaki et al. (1982) proposed a method called liquefaction potential index (LPI) which is derived from the $F S$ obtained from the empirical equation based on site investigation data. The $L P I$ was also used as a parameter to determine the level of liquefaction vulnerability on a site which was reported by Iwasaki et al. (1982) to generally occur up to the $20 \mathrm{~m}$ depth. This depth was, therefore, considered as the maximum in LPI calculation using Equation(4a) - (4c).

$$
\begin{aligned}
& L P I=\int_{0}^{20} F w(z) d z \\
& F=1-F S \text { for } F S<1 \\
& F=0 \text { for } F S \geq 1 \\
& w(z)=10-0.5 z \text { for } 0 \leq z<20 \\
& w(z)=0 \text { for } z \geq 20
\end{aligned}
$$

where, $L P I$ is the liquefaction potential index, $F$ is the weighting factor for $F S, w(z)$ is a weighting factor for depth and $z$ is the analysed depth. The range of liquefaction vulnerability on each site was, therefore, based on the LPI method presented in Table 1. 
Table 1. Liquefaction Potential Index ( $L P I)$ range (Iwasaki et al., 1982)

\begin{tabular}{lll}
\hline No & $L P I$ Ranges & Classifications \\
\hline 1 & $L P I=0$ & Very Low \\
2 & $0<L P I \leq 5$ & Low \\
3 & $5<L P I \leq 15$ & High \\
4 & $L P I>15$ & Very High \\
\hline
\end{tabular}

\section{RESULTS AND DISCUSSION}

The acceleration profile obtained from onedimensional seismic ground response analysis is presented in Figure 6. Meanwhile, the input motion shown in Figure 5 was applied at the bottom once the simulation was performed as elaborated in Section 2 after which the $a_{\max }$ parameter was obtained from the ground response analysis and further used for liquefaction potential analysis. Figure 6 shows the maximum acceleration is estimated at $0.9 \mathrm{~g}$ as indicated at a depth of $4 \mathrm{~m}$ for SI-3 while the minimum was $0.04 \mathrm{~g}$ at the ground surface of SI4 and the average maximum acceleration at the ground surface found to be approximately $0.314 \mathrm{~g}$. Moreover, the input motion applied at the bottom of the investigated site generally tends to undergo amplification and deamplification at the ground surface. Furthermore, $a_{\max }$ was used as the parameter input to calculate the liquefaction potential analysis.

Figure 7 shows the liquefaction potential analysis on each investigated site and, based on the elaboration from the previous section, Iwasaki et al. (1982) and Kramer (1996) reported the liquefaction was generally found up to $20 \mathrm{~m}$ depth. Therefore, the interpretation of the FS against liquefaction versus depth was presented up to $20 \mathrm{~m}$ with the threshold i.e. $F S=1$ indicated by a dashed line in Figure 7 . In general, $F S<1$ was reported for several sites such as SI-1, SI-3, SI-4,
SI-5, SI-6, SI-8, and SI-10 and this means they are susceptible to liquefaction during a large earthquake in Bengkulu City. Meanwhile, others such as SI-2, SI-7, and SI- have values larger than 1 and this means there is no likelihood of liquefaction during a large earthquake. Moreover, the site investigation data showed several soil layers dominated by poorly graded sand (SP), silty sand (SM), and clayey sand (SC) were relatively vulnerable to liquefaction during the Bengkulu-Mentawai Earthquake in 2007 while those with high soil resistance $\left(V_{s}\right)$ were relatively safe. The existence of clay layers in some of the sites such as SI-7, SI-9 tends to decrease the liquefaction potential due to the fact that clay layers have generally low permeability and this means there is no significant excess pore water pressure building up during seismic wave propagation.

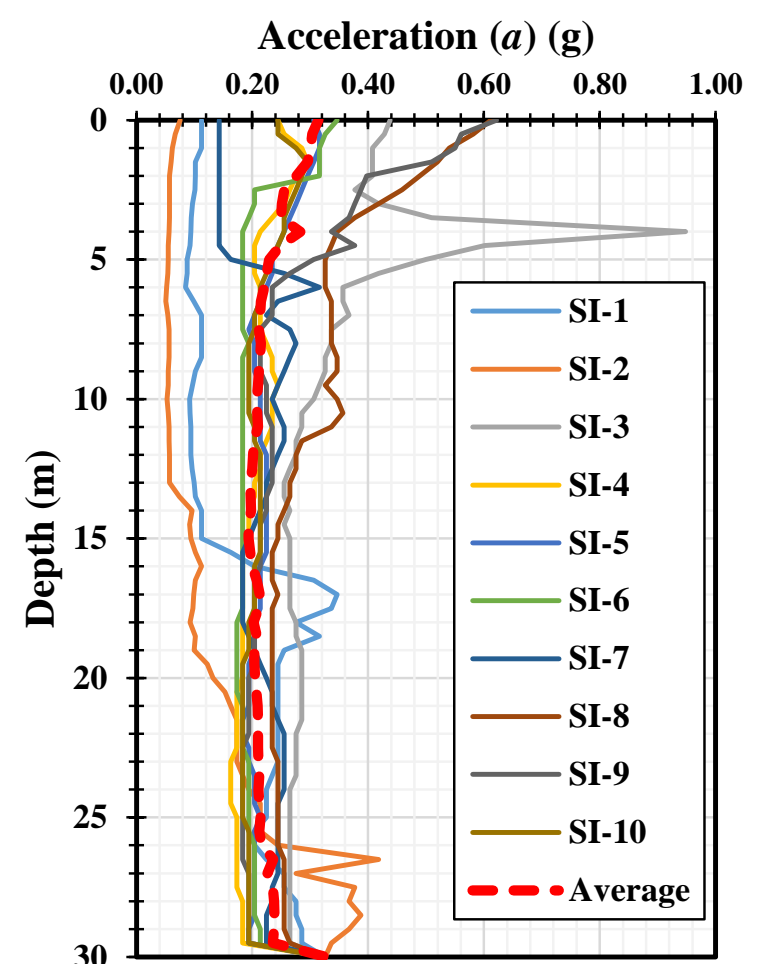

Figure 6. Maximum acceleration profile obtained from onedimensional seismic ground response analysis. . 

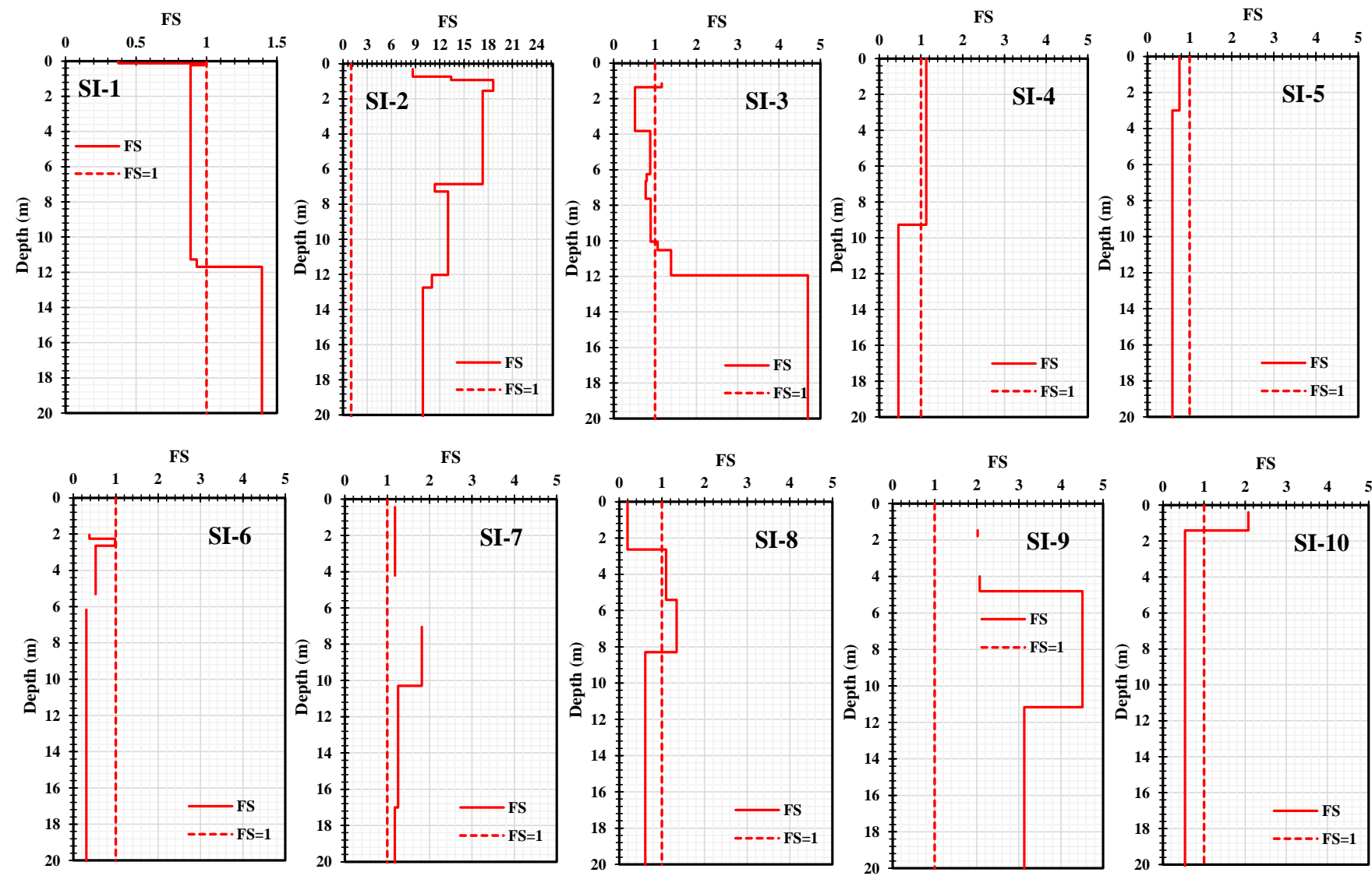

Figure 7. FS against liquefaction versus depth

Figure 8 shows the weighting factor with due consideration for the FS and depth analysed to determine the liquefaction potential index $(F w(z))$ in the study area. The value was, however, obtained by multiplying $F$ with $w(z)$. Similar with FS interpretation, the weighting factor corresponding to depth was found to be up to 20 $m$ depth and Figure 8 shows depth with low FS tends to have smaller $F w(z)$ as observed in SI-3, SI-5, SI-6, SI-8 and SI-10. These areas are simply predicted to be more vulnerable to liquefaction during a large earthquake.

Figure 8 and Table 2 show the LPI values obtained from the weighting factor analysis and the SI-1, SI-2, SI-4, SI-7 and SI-9 are categorised to have very low vulnerability for liquefaction. Those in SI-1 are located at Muara Bangkahulu, Sungai Serut, Gading Cempaka, and Ratu Agung Districts and observed to be dominated by swamp deposits, bintunan, and alluvium terraces formations. Table 2 also shows the $\mathrm{a}_{\max }$ values to be $0.08 \mathrm{~g}$ to $0.62 \mathrm{~g}$ in line with geological condition presented in Figure SI-2 with the areas observed to be dominated by sediment materials such as clays and sands while the Vs profiles of their layers are relatively larger. This indicates a larger soil resistance which makes it possible to control cyclic mobility produced during seismic wave propagation using cyclic resistance provided by soil properties. Some areas such as SI-3, SI-8, SI-5, SI-6 and SI-10 were categorised to have high to very high vulnerability and they are observed to be at Selebar, Singaran Pati, Kampung Melayu, and Teluk Segara Districts which are dominated by Tpan, Qa, QI, and Qat. The results also showed the $a_{\max }$ values at sites with high to very high susceptibility to liquefaction varied from $0.24 \mathrm{~g}$ to $0.61 \mathrm{~g}$ while those in those with very low to low susceptibility were found to be higher than 0.1g. Kramer (1996) and Day (2002), however, reported the possibility of liquefaction at sites with a minimum $a_{\max }$ of $0.1 \mathrm{~g}$ and the results also roughly estimated that $a_{\max }$ is not the main governing factor for liquefaction but soil strength, represented by Vs value, was considered to be very significant. 

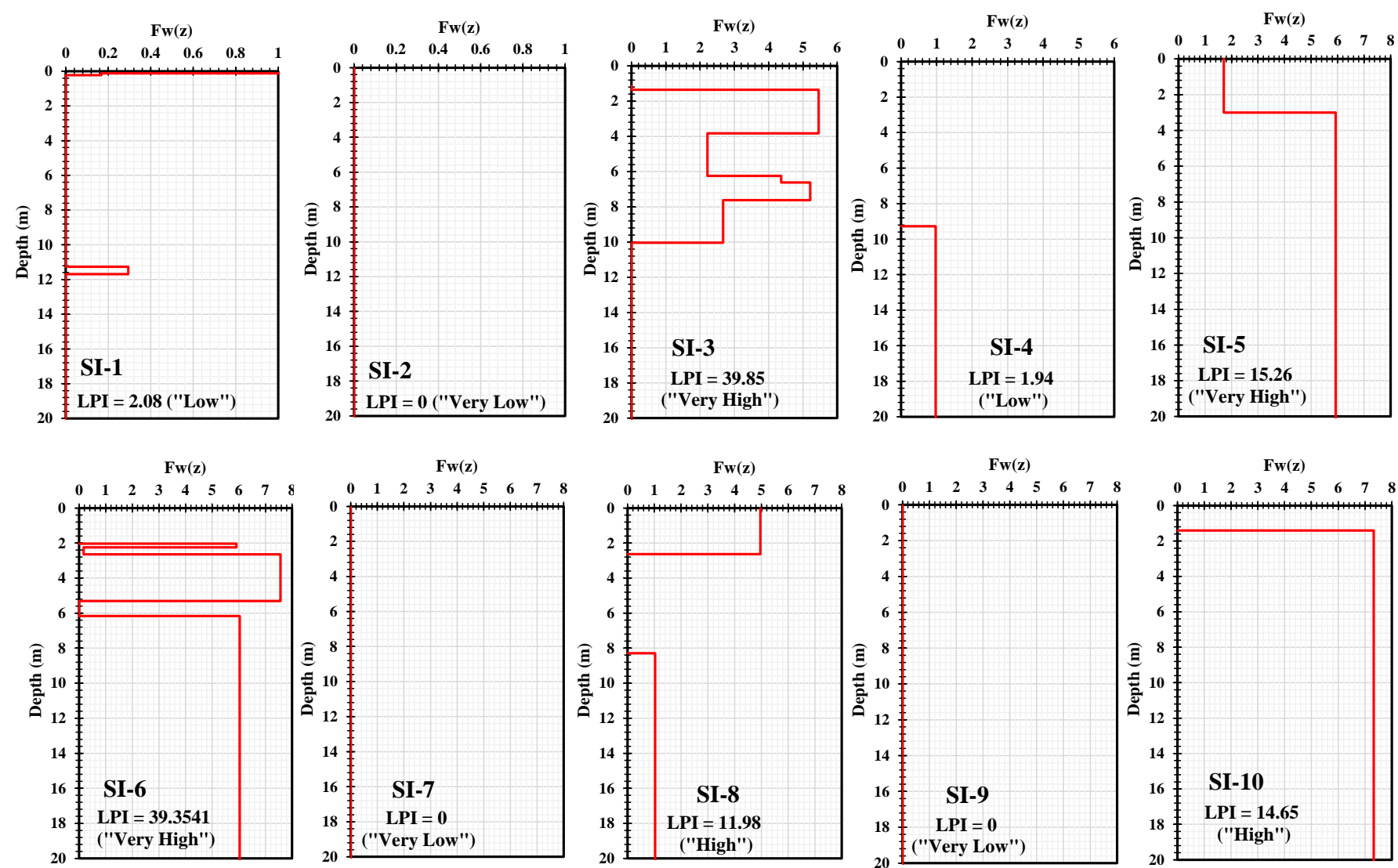

Figure 8. Weighting analysis of LPI

Table 2. Summary of LPI values and their categories

\begin{tabular}{llllll}
\hline Sites No & Sub-Districts & Geologic Formation & $a_{\max }$ & LPI Values & Vulnerability Categories \\
\hline SI-1 & Muara Bangkahulu & Qs & 0.11 & 2.08 & Low \\
SI-2 & Sungai Serut & QTb & 0.08 & 0.00 & Very Low \\
SI-3 & Selebar & Tpan & 0.44 & 39.84 & Very High \\
SI-4 & Kampung Melayu & Qat & 0.24 & 1.94 & Very Low \\
SI-5 & Kampung Melayu & QI & 0.31 & 15.26 & Very High \\
SI-6 & Selebar & Qat & 0.35 & 39.35 & Very High \\
SI-7 & Gading Cempaka & Qat & 0.14 & 0.00 & Very Low \\
SI-8 & Singaran Pati & Qa & 0.61 & 11.98 & High \\
SI-9 & Ratu Agung & Qat & 0.62 & 0.00 & Very Low \\
SI-10 & Teluk Segara & Qat & 0.24 & 14.65 & High \\
\hline
\end{tabular}

Therefore, there is a need for a comprehensive understanding of subsoils characteristic to determine the liquefaction potential in Bengkulu City which is one of the areas with the prospect for gradual development in the country. This means the findings related to the site characteristic presented in this study can be used as a preliminary judgement in measuring liquefaction potential in Bengkulu City.
The framework used in this study involves the combination of both numerical and empirical analyses which were generally implemented to predict liquefaction potential in the study area in order to identify those with low to very high susceptibility. Farid and Mase (2020) showed the seismic hazard should be considered and mitigation efforts implemented in the policy to develop Bengkulu City as one of the tourist 
destinations in Indonesia. The earthquakes were, however, found to be the main issue (Mase, 2020a) and this means their liquefaction effect needs to be determined and the results of this study showed the possibility of its occurrence at shallow depth during the earthquake. This is a clue to be considered by local engineers, especially in designing the sub-structures such as the foundation and the need to intensively improve the soil for liquefiable layers using a method focused on increasing the soil strength. Finally, the results are also expected to lead to other studies with a focus on reducing the liquefaction effect on the structures.

\section{CONCLUSION}

This research showed the effect of implementing ground response analysis to quantify the liquefaction potential in Bengkulu City using 10 sites to represent sub-districts and geological formations. The framework used was successfully applied to determine the liquefaction vulnerability level in the study area and several variations were observed. The sites with high soil resistance were found to have relatively low vulnerability while those with low soil resistance have more vulnerability. This means those located in the western part of Bengkulu City or coastline area tend to be more susceptible due to the presence of more loose sandy soils. The results also showed the possibility of the peak ground acceleration not being the main factor controlling liquefaction but the subsoils characteristics and this means there is a need to focus more effort on this factor. The study further recommends that local engineers consider the impact of liquefaction in the study area, especially for the development of structures in the future. The authors also suggested the implementation of the framework used in this study to investigate the liquefaction in other areas.

\section{DISCLAIMER}

The authors declare no conflict of interest.

\section{ACKNOWLEDGMENTS}

This study was supported by the research fund from the University of Bengkulu under the scheme of competitive research with grant no. 2183/UN30.15/LT/2019. The authors appreciate the Soil Mechanics Laboratory and Geophysics Laboratory, the University of Bengkulu for the service provided in field measurement for this study.

\section{REFERENCES}

Adampira, M., Alielahi, H., Panji, M., \& Koohsari, H., 2015. Comparison of equivalent linear and nonlinear methods in seismic analysis of liquefiable site response due to near-fault incident waves: a case study. Arabian Journal of Geosciences, 8(5), pp. 3103-3118.

Andrus, R. D., \& Stokoe II, K. H., 2000. Liquefaction resistance of soils from shear-wave velocity. Journal of geotechnical and geoenvironmental engineering ASCE, 126(11), pp. 1015-1025.

Andrus, R. D., Stokoe, K. H., \& Hsein Juang, C., 2004. Guide for shear-wave-based liquefaction potential evaluation. Earthquake Spectra, 20(2), pp. 285-308.

Day, R. W., 2002. Handbook of Geotechnical Earthquake Engineering. McGraw-Hill, New York.

Elgamal, A., Yang, Z., and Lu, J., 2006. Cyclic1D: A Computer Program for Seismic Ground Response. Report No. SSRP-06/05, Department of Structural Engineering, University of California, San Diego, La Jolla, CA.

Farid, M., \& Hadi, A. I., 2018. Measurement of Shear Strain in Map Liquefaction Area for Earthquake Mitigation in Bengkulu City. Telkomnika, 16(4), pp. 1597-1606.

Farid, M., \& Mase, L. Z., 2020. Implementation of Seismic Hazard Mitigation nn the Basis of Ground Shear Strain Indicator for Spatial Plan of Bengkulu City, Indonesia. International Journal of Geomate, 18(69), pp. 199-207. 
Idriss, I. M., \& Boulanger, R. W., 2006. Semiempirical procedures for evaluating liquefaction potential during earthquakes. Soil Dynamics and Earthquake Engineering, 26(2-4), pp. 115-130.

Iwasaki, T., Arakawa, T., and Tokida, K., 1982. Simplified procedures for assessing soil liquefaction during earthquakes." In: Proceeding of the Conference on Soil Dynamics and Earthquake Engineering, July 13-15, Southampton, UK, pp. 925-939.

Kramer, S. L., 1996. Geotechnical Earthquake Engineering. Prentice Hall, New Jersey.

Mase L. Z., Likitlersuang, S., Tobita, T., 2018. Non-linear site response analysis of soil sites in Northern Thailand during the Mw 6.8 Tarlay earthquake. Engineering Journal, 22(3), pp. 291303.

Mase, L. Z., 2017. Liquefaction potential analysis along coastal area of Bengkulu Province due to the $2007 \mathrm{Mw}$ 8.6 Bengkulu earthquake. Journal of Engineering and Technological Sciences, 49(6), pp. 721-736.

Mase, L. Z. 2015. Earthquake Characteristic in Bengkulu. Teknosia, 2(15), pp. 25-34. (in Indonesian)

Mase, L. Z., \& Somantri, A. K., 2016. Liquefaction Study Using Shear Wave Velocity $\left(V_{s}\right)$ Data in Coastal Area of Bengkulu City. In: Proceeding of Geotechnics National Seminar, August 11, Yogyakarta, Indonesia, pp. 81-86.

Mase, L. Z., 2018. One Dimensional Site Response Analysis of Liquefaction Potential along Coastal Area of Bengkulu City, Indonesia. Civil Engineering Dimension, 20(2), pp. 57-69.

Mase, L.Z., 2018. Study on reliability of liquefaction analysis method using SPT data due to the $M_{w}$ 8,6 Earthquake on September 12, 2007 on the coastal area of Bengkulu City. Civil Engineering Journal, 25(1),

Mase, L. Z., 2019. Performance of NGA Models in Predicting Ground Motion Parameters of The
Strong Earthquake. Journal of the Civil Engineering Forum, 5(3), pp. 227-242.

Mase, L. Z., 2020b. Liquefaction Potential Analysis Based on Nonlinear Ground Response on the Coastline of Bengkulu City, Indonesia. Makara Journal of Technology, 24(1), pp. 34-42.

Mase, L. Z., 2020b. Seismic Hazard Vulnerability of Bengkulu City, Indonesia, Based on Deterministic Seismic Hazard Analysis. Geotechnical and Geological Engineering 38, pp. 5433-5455 (Online first)

Mase, L.Z., Farid, M., Sugianto, N. 2019. The effort to mitigate liquefaction hazard for spatial development in Bengkulu City. Final Report. No. 2183/UN30.15/LT/2019, University of Bengkulu, Bengkulu, Indonesia.

Mase, L.Z., Tobita, T. \& Likitlersuang, S., 2017. One-dimensional Analysis of Liquefaction Potential: A Case Study in Chiang Rai Province, Northern Thailand. Journal of Japanese Society of Civil Engineers, Ser A1 (Structural Engineering/Earthquake Engineering), 73(4), pp. I_135-I_147.

Misliniyati, R., Razali, M. R., \& Bahri, S., 2014. Liquefaction Probability Map in Lempuing Subdistrict of Bengkulu City based on cone penetration test. Inersia, 6(1), pp. 53-60.

National Earthquake Hazards Reduction Program (NEHRP), 1998. Recommended provisions for seismic regulation for new building and other structure, 1997 edition, Part 1-provisions, Part 2commentary. Washington D. C., USA: FEMA 302

Natural Disaster Agency of Bengkulu Province (BPBD), 2018. Geological map of Bengkulu City, Indonesia. Natural Disaster Agency of Bengkulu Province (BPBD). Bengkulu, Indonesia

Pender, M. J., Orense, R. P., Wotherspoon, L. M., \& Storie, L. B., 2016. Effect of permeability on the cyclic generation and dissipation of pore pressures in saturated gravel layers. Geotechnique, 66(4), pp. 313-322. 
[This page is intentionally left blank] 